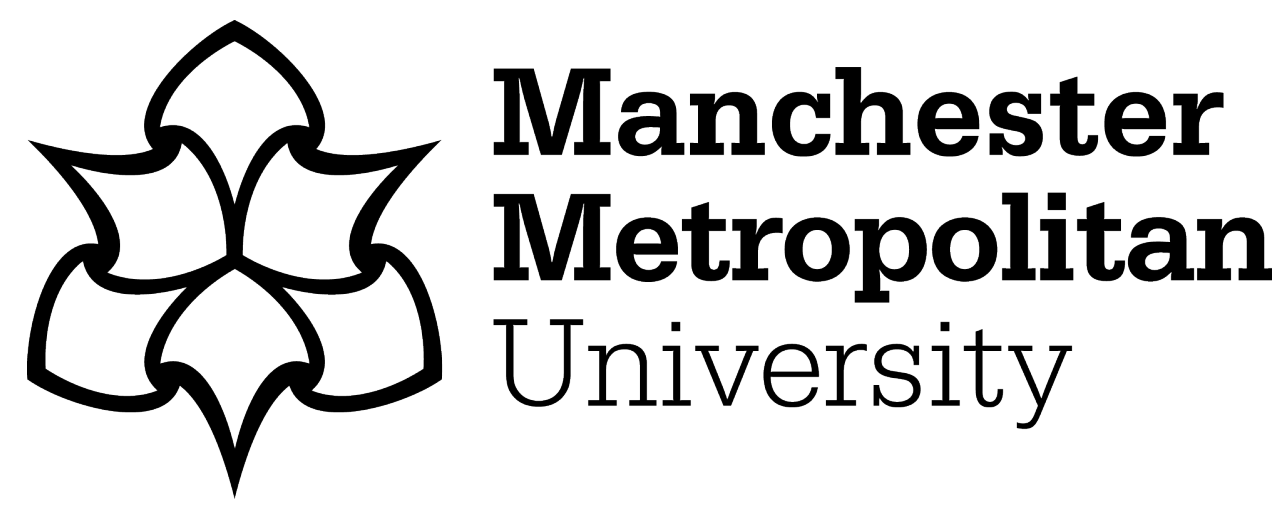

Smithson, Hannah, Gray, Paul ORCID logoORCID: https://orcid.org/00000002-1546-9333 and Jones, Anna (2021) "They really should start listening to you": the benefits and challenges of co-producing a participatory framework of youth justice practice. Youth Justice: an international journal, 21 (3). pp. 321-337. ISSN 1473-2254

Downloaded from: https://e-space.mmu.ac.uk/625013/

Version: Accepted Version

Publisher: SAGE Publications

DOI: https://doi.org/10.1177/1473225420941598

Please cite the published version 


\title{
"They really should start listening to you": The benefits and challenges of co-producing a participatory framework of youth justice practice
}

\author{
Hannah Smithson, Paul Gray, Anna Jones
}

\begin{abstract}
This paper presents the findings from a pioneering project between a university and 10 regional youth justice services. The project resulted in the co-production, with young people, of a framework of principles termed 'Participatory Youth Practice' (PYP). The benefits and challenges of producing PYP are discussed. We argue that the framework-grounded in Article 12 of the UNCRC and 'child first, offender second' principles - is a formative step in the process of creating a youth justice system that respects and acknowledges children and young people's rights, and enables them to meaningfully participate in decision-making processes.
\end{abstract}

\section{Key words}

co-production, young people, rights, participation, practice, policy

\section{Introduction: A Participatory Approach to Youth Justice}

While youth justice systems across Europe have generally been considered reductionist, lacking in solutions, and committed to political rhetoric (Goldson, 2010; Haines and Case, 2015; Phoenix, 2016), over the last decade, academics have started to look beyond governmentality frameworks, risk paradigms, responsibilisation and populist punitiveness (see Case and Haines, 2009; Muncie, 2009; Goldson, 2010; Phoenix, 2016). Indeed, more recently, academics in this field (Haines and Case, 2018; Smith and Gray, 2018; Case and Hampson, 2019) have laid down the gauntlet for others to enter into the debate regarding the future of youth justice systems, and in what form they may evolve. As Case and Hampson (2019:15) reflect, the present English and Welsh youth justice system represents an 'open playing field for those seeking meaningful change'.

The research project on which this paper is based was influenced by Haines and Case's (2015) 'child first, offender second' (CFOS) model. CFOS is founded on the belief that 'children are part of the solution, not part of the problem' (Haines and Case 2015:45). As such, the CFOS model inherently advocates for the participation of children and young people in decisionmaking and intervention processes. Indeed, two of the models eight key principles are 'children in justice systems should have access to their rights' and 'the voice of the child should be listened to' (ibid.:287). The value of adopting the CFOS model has been evidenced in the approach of the Swansea Bureau (Haines, Case, Davies and Charles, 2013) the Youth Justice Board's participation strategy (YJB, 2016), and the HMIP's framework for youth justice services (HMIP, 2017). While the CFOS model appears to be gaining traction in England and Wales, in line with Case and Hampson (2019), we assert that the continued lack of a coherent model of children and young people's participation in current youth justice practice highlights the need for the development of a new model of practice that is not solely reliant on adultdirected research. By building on the CFOS model, we focus on the co-production - with young people involved in the English youth justice system - of a participatory framework we term Participatory Youth Practice (PYP). This unique co-productive element both advances CFOS, and differentiates PYP from the CFOS model. We are of the opinion that rather than involving children and young people in the process of identifying and then negotiating the barriers to 
reform, there must instead be a pursuit of co-produced wholescale system re-design, with the view to developing youth justice practice that is inherently void of barriers to participation, and consequently young-person centric. The creation of the PYP framework is a formative step in this process.

\section{Review of the Literature: Children and Young People's Rights and Participation in Youth Justice}

The UNCRC General Comment No 24 (2019) on children's rights in the child justice system, replaces general comment No. 10 (2007) on children's rights in juvenile justice, reflecting developments that have occurred since 2007. Effective participation in the proceedings (art. 40 (2) (b) (iv)), states that, "a child who is above the minimum age of criminal responsibility should be considered competent to participate throughout the child justice process." Academics have recently sought to document the extent to which the United Nations Convention on the Rights of the Child (UNCRC) has been incorporated into international law and policy. In a special issue of the Journal of International Human Rights, Gadda, Harris, Tisdall, Millership and Kilkelly (2019) set out the case for the importance of analysing and understanding how countries have implemented UNCRC principles. Much is made of Scotland's advances in its moves to incorporate the UNCRC into policy and legislation and its commitment to undertake an audit of the extent to which UNCRC principles have been implemented; referred to as the 'CRC Audit' (see 2018-19 Programme for Government, Scottish Government, Delivering for Today, Investing for Tomorrow). In a Welsh context, the government have incorporated Article 12 of the UNCRC - 'the right (for children) to have their views given due weight in all matters affecting them in accordance with their age and maturity' - into legislation, thereby explicitly committing authorities to the 'consultation and the participation of ... young people in the youth justice system' (Nacro Cymru, 2009:1). Similarly, in Ireland, a checklist of four interrelated elements - space, voice, audience and influence - needed to enable children and young people's participation in decision-making (Lundy 2007) has been incorporated into Ireland's National Child Participation Strategy (2015), thereby embedding children and young people's participation in 'every government department and agency' in Ireland (Byrne and Lundy, 2019:362). Alongside the UK, a number of other European countries, notably Sweden and Belgium, have passed Government Bills dictating that all government decisions affecting children and young people are to be subject to child impact assessments (Byrne and Lundy, 2019).

In contrast, the incorporation of UNCRC principles into the youth justice context remains 'arbitrary and uneven' (Scraton and Haydon, 2002:324). For example, Smith and Gray's (2018) study of youth justice service delivery across England found that only three youth justice services (Leeds, Gateshead and Norfolk) explicitly cited youth participation as a commitment in their annual business plans. Notwithstanding this, within discrete projects, children and young people's participation has been successfully adopted within justice settings. For example, in the early 2000s, the San Francisco Juvenile Justice Evaluation Project (London, Zimmerman and Erbstein, 2003) involved a team of adult researchers supporting a team of twenty youth researchers (all with experience of the justice system) to evaluate the effects of the project. The young people were supported to open up a dialogue with other young people in the justice system about their needs and experiences, to develop indicators to measure the success of the project, and to present the findings and recommendations to policy makers. The project improved meaningful relationships between practitioners and young people, promoted effective dialogue, and developed transformative youth-led ways of working. More recently, work undertaken in Scotland by Lightowler and Cook (2015) focussed on understanding how 
children and young people could become active participants in shaping improvements to youth justice policy, practice and research. Working with young people who had differing levels of experience with youth justice services, a number of ideas were developed, including an annual engagement event with young people and service providers, the development of peer support programmes, and the establishment of youth advisory groups within youth justice services. One of tangible benefits to come out of this piece of research is a group of young people contributing to the Scottish 2015 Youth Justice Strategy (Scottish Government, 2015).

Yet notwithstanding the positive outcomes that can result from engaging children and young people in a participatory manner, the fact remains that youth justice initiatives such as the ones described above are relatively rare. They are reliant on those with power - for example, policy makers - supporting transformative action (see Vaughan, 2014) and are invariably limited to positively effecting a discrete initiative at one point in time. Despite Article 12 of the UNCRC clearly stating that children and young people's views should be sought in all matters affecting them, as Byrne and Lundy (2019) note, there are a number of challenges to the meaningful participation of children and young people in decision-making processes. These include, a lack of awareness among children and young people that they have the right to be heard and taken seriously, a lack of awareness among adults that children and young people have this right, and that certain groups of children and young people may lack equity of access to participation. This final point is particularly pertinent when it comes to children and young people in the youth justice system. However, by excluding them from decision-making processes, we are ignoring the valuable expertise they possess, and are consequently missing the opportunity to leverage this to address offending behaviour. Instead, we are left with youth justice systems that are characterised by top-down approaches, system-led processes, adult-devised standardised assessment tools, and a preoccupation with managing risk - all of which serve to ignore children and young people's rights, depersonalise interventions, and devalue their expertise in their own lives. For these reasons, the PYP framework described in this paper works toward a goal of supporting meaningful participation. By this, we mean ensuring that children and young people are aware that they have the right to be heard, and that they have equity of access to participate in those stages of the justice system where decisions about them are being made.

\section{Methods: Our Approach}

\section{Project Conception}

The project was an innovative two-year Knowledge Transfer Partnership (KTP) ${ }^{i}$ between a university and 10 regional youth justice services in the North West of England, UK. As part of the KTP, the third author of this paper, Anna, was seconded from the university to each of the youth justice services for a period of two years. She spent a considerable amount of time with youth justice practitioners, observing first-hand the work they carried out on a day-to-day basis. Her observations of practice revealed that, overall, the principles of managerialism and responsibilisation created barriers for practitioners to get much beyond the building of a good rapport with young people. As such, the project focussed on (i) redressing the balance of youth justice practice, with a focus on the participation of young people, rather than the ideological principles of managerialism and responsibilisation, and (ii) piloting a new model of working with a focus on the bi-directional transfer of knowledge between young people and the research team. Outlined below is an account of how the young people were active agents in what became the PYP framework. For ease of understanding, each research stage is described separately. 


\section{$\underline{\text { Research Stage 1: Engaging Young People }}$}

Although the criteria for involvement in the project was very loose - young people had to be aged between 15 and 18 years old with experience of involvement with the regional youth justice services - it was challenging to get the project high on practitioners' agendas. It was difficult to drive something that was viewed as a 'good thing' to do, rather than a fundamental element of a service operating with limited resources, in a pressurised environment, working with young people in and out of crisis.

Despite these challenges, over a period of six months, 50 young people were nominated by youth justice colleagues, and Anna had informal conversations with each of them. As part of our ethical responsibility to the young people, it was made very clear to them that although their youth justice worker had nominated them, there was no obligation to take part in the project. Of the original 50, 28 young men expressed an interest in working with the research team. All 28 had experience of repeated and/or prolonged involvement with the youth justice system. Their average age was 17 , and a third were from ethnic minority backgrounds. Over two thirds were exposed to at least one adverse childhood experience growing up, including bereavement or significant loss, physical abuse and/or neglect, emotional abuse and/or neglect, and familial substance use. In addition, more than half were, or had previously been, in local authority care. While we actively attempted to engage young women into the project, it was not possible. This was the result of a combination of factors. At the time of the research there were low numbers of young females involved with youth justice services across the region, and those that were, were not subject to statutory orders that mandated engagement with the justice service.

Over the six-month period, Anna undertook semi-structured interviews with each of the 28 young people. Common discussion points included, family backgrounds, their experiences of the youth justice system, and how they felt the justice system could better understand these experiences and better meet their needs. Participatory research often uses creative techniques such as art, writing and film-making (see Kim, 2016). With this in mind, Anna also spoke to each of them about what activities the project could potentially offer (within the funding and time constraints). During this time, a gradual consensus was reached around how the young people wanted the project to develop. While a number of them expressed an interest in physical activities - such as football and boxing - others mentioned music (predominately grime), street art, and creative activities. Bearing in mind that participatory activities should reflect the interests of young people (Iwasaki, Springett, Dashora, McLaughlin, McHugh, and Youth 4 YEG Team, 2014), in due course, a series of one-day workshops focused around boxing, grime lyric writing, and urban art were developed. Using the participatory principle of the adult facilitator acting in a 'support role' (Ozer, 2016:264), we then identified professional facilitators for each of these workshops.

\section{$\underline{\text { Research Stage 2: Co-Producing and Delivering Creative Workshops }}$}

While it is not the purpose of this paper to provide a detailed account of the relative merits of each creative activity, some description of the process is necessary to provide the methodological context. One of the key principles of participatory research is participation and action (Kidd and Kral, 2005) and the young people we were working with shared common identities and interests (Banks, Armstrong, Carter, Graham, Hayward, Henr, and Strachan, 2013). We therefore decided, with them, that the activities would be most valuable if they were run as group sessions. This would support the collective generation of knowledge, and at an 
individual level, have the potential to increase research and communication skills, and improve critical awareness of social problems (Berg, Coman and Schensul, 2009). Each of the workshops was held at an appropriate venue for the activity, and each workshop was cofacilitated (along with research team) by the identified professional facilitator/s. The workshops were a means of working more closely with the young people and exploring in more detail the discussion points raised in their interviews. They were planned to include the chosen activities, interspersed with discussions of their experiences of the youth justice system. As detailed above, the majority of the young people were dealing with complex issues and were facing multiple challenges of their own. As such, there were instances when they did not show up to pre-arranged workshops, or if they did, they were unwilling to fully engage.

The use of boxing as an activity is well-established among those that work with young people. It is has been shown to be a particularly beneficial engagement tool when working with young people at risk of, or in conflict with the law (see Jump and Smithson, 2020). The boxing workshop raised discussion points about respect, discipline, confidence, and trust. Likewise, the role of arts including the writing of poetry and prose, and the subsequent performance of this writing, has shown to be an effective engagement approach for young people in criminal justice settings (see Winn, 2010). The grime lyric writing workshop raised issues around the value of legitimacy and authenticity, as well as frustrations over young people's lack of voice. Arts-based approaches are also frequently utilised in research with marginalised groups. They have the transformative potential of developing artistic skills, while providing an alternative platform for expressing thoughts and experiences (see Nunn, 2010). The urban art workshop created discussions around identity, the need for second chances, and for others to understand the reasons behind young people's offending behavior.

While not all 28 of the young people participated in the workshops (a total of 15 participated, five of whom attended more than one workshop), through their participation in the initial interview phase, they each influenced the development of the research through their ownership of specific elements of the project; creating what Franks (2011:22) refers to as "pockets of participation'.

\section{$\underline{\text { Research Stage 3: Co-Analysis and Dissemination }}$}

Fear, Rosaen, and Bawden, (2006) view the data analysis phase as vital in providing participants in co-creative research with an opportunity to critically reflect on the data. With this in mind, those who had participated in the workshops were all supported to be involved in the analysis of the data generated from the 28 initial interviews and the three workshops. Due to their constantly evolving personal circumstances (which included, for example, custodial sentences, loss of accommodation, mental health issues, or simply being unwilling to be involved with the project), three of the 15 young men who attended the workshops were involved in the analysis stage.

The initial interviews and the discussions from the workshops were fully transcribed. These transcripts, along with the outputs from the workshops (in the form of flip chart exercises, lyrics, and photographs of the artwork produced) were analysed by the authors. Coding began by balancing inductive and deductive theorising (see Thew, Middlemiss and Paavola, 2020), and broad search terms such as youth offending teams, police, mental health, drugs, voice, power, and risk were developed as topics for enquiry. A number of themes emerged from the analysis. These included the young people: (i) feeling they had little say in their lives; (ii) wanting recognition from others that they had experienced hardships in their lives; (iii) 
expressing a desire to change their lives, but not having the social capital to do so; (iii) feeling that others did not understand them; (iv) feeling that they were not being given a second chance; (v) having their strengths and skills ignored; and (vi) disagreeing with the sanctions imposed upon them.

These themes were then presented to the three young people at an additional series of analysis workshops. It was explained that they were a summary of what young people, including themselves, had said about their experiences of the youth justice system. It was also heavily emphasised that these themes were open to challenge. They changed the language and reexplained certain things, based on their own experiences, which led to a more expansive discussion of things that were pertinent to them. This resulted in some themes being expanded, while others were collapsed. After a series of iterations, a final set of six co-created themes were agreed upon. These themes became the formulating principles on which PYP is based.

The final stage of the project involved the dissemination of the PYP framework. We asked the young people how they wanted to do this. They agreed that they wanted to create some lyrics. Working with the original facilitator from the grime lyric writing workshop, they created a set of lyrics that explained the principles of the PYP framework. They were then set to a film, to be used as an explainer for youth justice practitioners. A link to the film can be found here https://www.mmu.ac.uk/mcys/gmyjup/pyp/.

A workshop explaining the PYP framework to regional youth justice practitioners was then delivered by the research team. Alongside this, each of the 10 youth justice services nominated a 'Participation Champion', whose role it is to support the implementation of the PYP framework in practice. Furthermore, a suite of resources and guides on how to embed PYP principles in practice was created. The resources were made available for download on the project website and can be accessed here https://www.mmu.ac.uk/mcys/gmyjup/pyp/.

By providing the young people with the opportunity to become active agents in the research, this project moved beyond simply focusing on the subjective experiences of young people in the justice system, to using these experiences to co-produce a tangible framework of practice principles. In the next section, we present the PYP principles that emerged from the research stages outlined above.

\section{Findings: The Participatory Youth Practice Principles}

The principles that emerged are: 'let them participate'; 'always unpick why'; 'acknowledge limited life chances'; 'help problem solve'; 'develop ambitions and options'; and, 'afford them a fresh start'.

\section{Principle 1: Let them participate}

They really should start listening to you, ... but they just go through what they've got to do. That's their procedure. That's their job. (Ant, aged 15)

The above quote highlights the lack of opportunity the young people felt they had to meaningfully contribute to the justice system's response to their offending behavior. This emphasises the salience of Lundy's (2007) findings. As Jermaine (aged 17) put it; 'They don't listen to you ... they don't let you speak ... so they don't understand nothing'. With this in mind, the young people's lack of investment in the work they were undertaking with the youth 
justice service - evidenced by comments such as 'I don't care' and 'I'm just going to get it over and done with' - become more understandable. Yet it has been shown that when participation is used in a justice setting it can transform practice through increasing engagement with the system and building better relationships between young people and practitioners (see London, Zimmerman and Erbstein, 2003).

Furthermore, we would argue that there is a relationship between levels of participation and how young people view the legitimacy of their treatment within justice systems. This is of central importance because it has been shown that a lack of perceived legitimacy has a detrimental impact on the extent to which any punishment metered out by a justice system can be considered just (Phoenix, 2016). This in turn can have a negative impact on how any order is received. In an echo of Barry's (2013:55) findings, while the young people could appreciate the 'purpose' of their orders, they queried their 'delivery' and their 'effectiveness'. As one of the young people succinctly summed up:

You can't just do it because somebody says, "You've got to do this". You don't do it for that. You do it because you want to do it.... You don't need people to make decisions for you. (Josh, aged 16)

We argue that there is a disparity between those who create youth justice policy and practice and young people themselves, with differences in whose knowledge is valued, and barriers relating to how knowledge is shared across boundaries. These disparities are a common criticism of the integration of UNCRC principles into policy and legislation (Kilkelly, 2019). However, by embedding the principles of the PYP framework into practice, we seek to facilitate young people's participation in service design and delivery, rather than simply 'encouraging' them to participate. Hence principle 1: 'let them participate'.

\section{Principle 2: Always unpick why}

They've got to understand that there are ... reasons why you do shit. (Jay, aged 16)

The importance of participation was further evidenced by the young people's view that the youth justice system needed to pay more attention to the reasons why they had offended in the first place. An approach very much fitting within the CFOS model (Haines and Case, 2018). From their point of view, identifying and acknowledging the underlying factors that may have contributed to their offending behaviour is of central importance when it comes to delivering interventions aimed at addressing that behaviour. The participatory methodology adopted in this project enabled us to get to know the young people well. As we met on numerous occasions, they became more comfortable talking about their lives and the reasons why they had offended. Ste (aged 17) spoke candidly about his substance abuse and his chaotic family life. At the time of the research, he was living in supported housing and had experienced homelessness on a number of occasions.

I don't care. That's the reason I take drugs. To avoid the problems of life. You know, my story, it's complicated. My dad was a smackhead. He never bothered with me for 18 years. I was told he was dead before I found out one of my family members was lying. It's stuff like that.

In recent years there has been a notable increase in the number of children and young people entering justice systems who describe themselves as having mental health problems and/or substance use issues, as well as having spent time in local authority care (see Gyateng, Moretti, 
May and Turnbull, 2013; Bateman, 2017; Fitzpatrick and Williams, 2017). This is indicative of an increasingly complex set of needs among the demography of children and young people within justice systems (Baldry, Briggs, Goldson and Russell, 2018). For example, Tommy (aged 17) - who had grown up in care, had no contact with his family, was living in supported housing, was suffering with a number of mental health problems, and was a heavy cannabis user - spoke of how these experiences contributed to his offending. It is clear that the intersectionality of complex needs, such as those experienced by Tommy, impacts upon the likelihood of contact with the youth justice system (see Dowse, Cumming, Strnadova, Lee and Trofimovs, 2014).

If you're in somewhere like I am, what have you got to do all day? Sit there in your room and go crazy? I'm sat in my room smoking weed all day, literally staying up until six or seven in the morning, going out, trying to get more money for the weed, because [otherwise] I'm just sat there doing nothing. That's the way I've lived my life.

However, in addition to a young person's needs, is the impact of deviant peer groups. The relationship between deviant peers and young people's offending behaviours is well established. For some (see Hawkins, Herrenkohl, Farrington, Brewer, Catalano, Harachi and Cothern, 2000), it presents one of the strongest risk factors in predicting youth offending. For example, Reyhan (aged 17) spoke of peer group pressure in relation to the robbery for which he received a custodial sentence.

It was just one day we were just all giddy. I never wanted to do it but my mate forced me to do it. I went with my mate. Apparently, they owed him some money or something, so I just went with him.

However, when discussing what advice he would give to professionals working within the youth justice system, Reyhan spoke candidly about the need for the justice system to acknowledge the unique period of adolescence and the challenges it brings.

The judges need to understand that kids mess about ... until a certain age [and] not give them a custodial sentence straight away.

While adolescence and the transition to adulthood involves learning the norms and values of wider society (Sanders, 2013), for socially excluded and marginalised children and young people in particular, the adolescent life stage holds even less status and offers little guidance for transitioning to adulthood (Barry, 2002). The second principle of PYP - 'always unpick why' - reflects the need for youth justice systems to respond to children and young people's offending behaviour with an understanding that behaviours can be shaped by experiences that they are 'unable to change or affect' due to their status as children in a legal and developmental sense (Phoenix, 2016:135).

\section{Principle 3: Acknowledge limited life chances}

People say ... that you can be whatever the fuck you want. But ... you can't just do whatever the fuck you want. That's a lie. ... You need money behind you and stuff like that. ... It's just how it is. (Ste, aged 17)

The third principle of PYP is related to the fact that all of the young people in this project spoke of the limited opportunities they felt they had in their lives. Gray (2009) suggests that, although 
opportunities for young people in justice systems are limited (when compared to those not in the justice system), there remains an implicit expectation (at a policy level) that young people themselves can successfully navigate this lack of opportunity. However, by emphasising individual transformation in this way, contemporary youth justice policy assume that young people have both the capacity and freedom to make the right choices (Gray: ibid.). In reality, their often complex and chaotic lives simply serve to restrict their opportunities. For example, Josh (aged 17), who was living in temporary accommodation with his girlfriend, spoke of the difficulties he faced finding employment.

I've applied for well over 200 jobs and not a single place [has] got back [to me]. ... So you've got $£ 200$ to last you a month. Gas, electric, rent, food, clothes if you need them. It isn't going anywhere.

Yet despite the young people's acute awareness of the challenges they faced - owing to their socio-economic backgrounds, prior lived experiences, and repeated/prolonged contact with the justice system - it is notable that in the vast majority of cases, they avoided descending into overwhelming pessimism. Indeed, most still nurtured big ideas or plans for their futures, with the emergence of pro-social identities clearly evident. A number of them spoke at length about their desire to lead a 'normal' life, indicating that they had the agency to desist from further offending (Giordano, Cernkovich and Rudolph, 2002). Patrick (aged 17) described his attempts to obtain employment and made it clear that he was willing to try anything if it afforded him a legitimate wage.

I want it to be legitimate money. ... Not having to worry about getting raided. Not having to worry about going back to jail. If I had a job now shoveling shit that was a decent wage, I'd go and do it.

Patrick's words illustrate how young people can either, 'accept and conform to ... political and economic arrangements ... likely to keep them in a state of perpetual economic marginalisation and social exclusion' (Gray, 2009:453), or they can continue to be in conflict with the justice system. When young people are confronted with this stark choice, the relative appeal of continuing to operate outside the law (despite the potential negative consequences associated with this course of action) becomes more relatable, and the barriers to desistance better understood. With this in mind, the third principle of PYP - 'acknowledge limited life chances' - argues that it is important that practice adequately considers the 'why' that lies behind young people's behavior. Indeed, it is crucial that youth justice practice actively acknowledges these challenges to the young people, articulating an appreciation of their significance on behalf of the justice system.

\section{Principle 4: Help problem solve}

They [youth justice practitioners] have sorted me out a lot, but it doesn't get sorted out on its own, does it? It's not quick. Everything just takes time. (Tommy, aged 17)

While it is fair to say that pro-social identities were beginning to emerge, this was alongside an absence of increased social capital (Barry, 2010); indicating that, to some extent at least, many young people were attempting an agentic move towards desistance (Giordano, Cernkovich and Rudolph, 2002) despite their circumstances doing little to facilitate this. However, as McNeill, Anderson, Colvin, Overy, Sparks, and Tett, (2011) note, desistance does not occur in isolation. The young people's message was clear: once the factors that contribute to their offending have 
been identified and acknowledged, they are then looking for support in solving (or at least navigating) the problems they may be facing. As already highlighted, for most of the young people in this project, one of the main problems they faced was financial difficulties, resulting primarily from a lack of (legitimate) employment opportunities. For others, such as Jay (aged 16), a lack of suitable accommodation was also a pressing issue.

It's not just jobs that are hard to get, it's houses, flats. Round here there's blocks of flats called smackhead flats. They're all dodgy flats, they're never nice flats.

As detailed earlier, many of the young people had grown up in care and had limited experience of a consistent parent or guardian in their lives. As a consequence, they had developed a strong sense of independence. It was apparent that for many of them their experiences with the justice system had simply served to teach them the life lesson that 'they have to do things for themselves'. Jay (aged 16) expressed this sentiment using those exact terms: 'you've got to do it for yourself, that's what it's about'. Reyhan (aged 17) similarly explained: 'I just use my own initiative when I need something. I don't like relying on other people. ... I just do it myself'.

It is lamentable that the responsibilisation attained through contact with the justice system appears to be not a result of a system that is working as intended, but rather the result of repeated systematic failings. These failings serve to trigger the realisation in young people that there is an absence of support when it comes to problem solving (see Phoenix and Kelly, 2013:434). As McNeill, Anderson, Colvin, Overy, Sparks and Tett, (2011:8) note, 'desistance does not exist in isolation'. The young people in this project were clearly in need of support when it came to navigating the consequences and implications of their offending. For this reason, the fourth principle of PYP is 'help problem solve'.

\section{Principle 5: Develop ambitions}

I'd have a job any day. ... They call it the American dream don't they? Family, house, kids, pets. Just being able to relax. ... I would ditch all this and have an easy life. (Ty, aged 17)

Alongside receiving assistance with solving/navigating their problems, the young people also expressed the need for support in finding suitable, more positive, alternatives. While it was evident that they had ambitions and were motivated to stop offending, many were resigned to the fact that their past would limit their future goals and ambitions.

I'm a very fucked up person. ... I have been treated like shit all my life, so I don't expect myself to do well. I don't have a good opinion of myself. (Ste, aged 17).

In recent years there has been much emphasis in youth justice literature about the role youth justice practice can play in supporting children and young people's ambitions and goals (see Nugent, 2014; Fitzpatrick, McGuire and Dickson, 2015; Johns, Williams and Haines, 2016), helping and supporting them to find something positive to change for, rather than just negative consequences to avoid. While the implementation of Asset Plus in England and Wales should, in principle provide this opportunity - 'goals and life opportunities' is one of the five areas to be addressed in assessments (YJB, 2014) - Hampson (2018) found that the opportunity to enhance young people's strengths was routinely missed when completing Asset Plus assessments. In addition, she also found that practice missed opportunities for identifying and facilitating the increase of young people's social capital. 
Despite this, there were clear indications that the young people in our project were beginning to consider alternatives to offending, or, what McMahon and Jump (2018:6) term 'starting to stop', albeit on their own terms. However, as touched on earlier, for many children and young people in justice systems, the search for a non-offending identity can feel stifled by the (often limited) options available to them. This in turn can lead to an embrace of the one identity that is readily accessible to them: that of an offender. It is not a new observation that people with extensive experience in the justice system adopt, at least to some degree, the label or identity of an 'offender' in one form or other (McNeill, Farrall, Lightowler and Maruna, 2013). Indeed, many of the young people in this project referred to themselves as 'criminals'.

Wait until I've got it all sorted and then I can be like: 'Yes, I am actually standing on my own two feet. I've got my own place sorted. I've sorted my rent, my gas and electric. I've got food. I've got a nice flat, ... got nice things'. I want to show them [my family] that I can make it. I want to do that, but it's just... . (Jez, aged 17)

The 'but it's just...' at the end of Jez's account of his future ambitions is indicative of how many of the young people felt about their current situation. Fitzpatrick, McGuire and Dickson (2015:173) refer to this as being 'stuck in uncertainty'. This exemplifies the importance of the fifth principle of PYP: providing opportunities for young people to 'develop their ambitions'.

\section{Principle 6: Afford them a fresh start}

People just see the old me. I want people to see ... I'm not like that now. I've changed. (Jermaine, aged 16)

Barry (2013:62) argues that 'crime epitomizes a lack of recognition by the established community'. Therefore, as well as young people making a positive decision to reform their behaviour for themselves, it is also vital that the 'society into which they wish to integrate also makes a conscious effort to welcome them'. Typically, the young people we worked with did not experience recognition of their attempts to make a fresh start. For example, Kai (aged 16), whose family were well known in the area where he lived, described how he is routinely treated by the police.

The other day I'd literally just been out for some cigs, nothing else ... and there's a police car there waiting for me. They said: 'You match the description of a young male dressed in dark clothing that has been messing about putting road signs in the middle of the road'.

Jermaine (aged 16), who had a number of previous convictions, took steps under his own initiative to distance himself from friends and family in order to stay away from crime.

I'm staying away from the crowd. ... Every time they're out doing their stuff, I'm not.

Ultimately, young people like Jermaine had to consciously give up the benefits associated with offending (status, money, friendships, excitement) in the belief that a positive opportunity would emerge. This is a big ask, and one that it is easy to underestimate when children and young people's direct experiences are missing from youth justice discourse. When the choices can be seen through the lens of direct experience, the extent to which Jermaine and others are dedicated to the idea of turning their lives around begins to look, in fact, remarkable; emphasising the presence of a powerful 'ambition for normality and integration within 
mainstream society' (Barry, 2013:61). With this in mind, the sixth and final principle of PYP is: 'afford them a fresh start'.

\section{Discussion and Conclusion}

The outcome of the KTP project was the co-production, with young people, of a set of principles to inform youth justice policy and practice. As we have detailed, the PYP principles are grounded in children and young people's rights and an ethos of meaningful participation. From a research perspective, co-production supports children and young people to actively direct the process of knowledge construction through a consideration of their lived experiences (Fals Borda, 1987). Enabling the young people to co-direct this research project greatly enhanced the validity of the PYP framework. It is our intention that the principles of PYP will enable children and young people to get a sense that they, not only have control over their 'treatment' within the justice system, but that they also hold important expertise that can usefully inform youth justice policy and practice; both of which are prerequisites for a rightsbased approach to youth justice. Furthermore, PYP provides a source of individual social recognition and social capital for children and young people. For example, statements such as 'kids like us don't usually get these opportunities' and 'people don't usually bother asking us what we think' highlight the value of participation. Indeed, in the health and social care context, youth participation in the co-production of services has been shown to increase young people's confidence and positively impact upon treatment and recovery outcomes (NEF, 2009; Public Health England, 2015).

Yet, notwithstanding the obvious benefits of PYP, it is likely that embedding the framework in practice will not be without its challenges. Adopting the principles relies on an acceptance of children and young people's right to participate in decision-making; something that may cause policy makers and practitioners to question some of their own beliefs about the rights of children and young people within the justice system. Additionally, while we recognise that practitioners can be resistant to new systems (see Lipsey, Howell, Kelly, Chapman and Carver, 2010), this resistance is not always a result of cynicism; it can be a lack of confidence that the wider justice system will not adequately support them. It is telling that a decade on from the recommendations made in Voice and Influence in the Youth Justice System (National Youth Agency, 2010) young people's participation is still not always prioritised. For instance, even when practitioners are committed to integrating participatory approaches into their everyday practice, research has shown that a lack of resources, ingrained working practices, and a lack of interest from service users, can all be significant barriers (Fischer, Jenkins, Bloor, Neale and Berney, 2007).

To address these potential barriers, as described earlier, each of the youth justice teams identified a 'Participation Champion' to support their colleagues in understanding the framework, and how best to embed the PYP principles into everyday practice. Through our continued work with the teams, we are seeing some concrete examples of PYP being embedded into practice. For example, when overseeing young people's cases, one team has replaced a set of questions addressing risk with the PYP principles, while another has integrated the principles into their supervision sessions with young people. Through the creation of 'working groups' with young people, one of the teams has even facilitated the participation of young people in decision-making about the development and delivery of new initiatives and programmes.

To conclude, this paper has argues that unless youth justice policy and practice is co-produced with children and young people, youth justice systems risk simply reiterating what has gone 
before. The argument made here is that 'meaningful change' (Case and Hampson, 2019:15) requires moving beyond a system characterised by top-down approaches, adult-devised assessment tools, and a preoccupation with risk management, to a system that provides children and young people with space, voice, audience and influence (Lundy, 2007). With this in mind, it is clear that there is still much work to be done in justice settings to raise awareness around children and young people's rights (Byrne and Lundy, 2019). Nonetheless, we contend that the overall ethos of the PYP framework - grounded in CFOS, co-production, and meaningful participation - can contribute to the advancement of youth justice systems built on the notion of respecting and acknowledging children and young people's rights and enabling them to contribute to decision-making processes.

\section{References}

Baldry E Briggs D Goldson B and Russell S (2018) 'Cruel and unusual punishment': an interjurisdictional study of the criminalisation of young people with complex support needs. Journal of Youth Studies 21(5): 636 - 652.

Banks, S., Armstrong, A., Carter, K., Graham, H., Hayward, P., Henr, A.,\& Strachan, A. (2013). Everyday ethics in community-based participatory research. Contemporary Social Science: Jounal of the Academy of Social Sciences, 8(3), 1-15.

Barry M (2002) Minor rights and major concerns: the views of young people in care. In: The New Handbook of Children's Rights: Comparative Policy and Practice. London: Routledge, pp. $239-253$

Barry M (2010) Youth transitions: from offending to desistance. Journal of Youth Studies 13(1): $121-136$.

Barry M (2013) Desistance by Design: Offenders' Reflections on Criminal Justice Theory, Policy and Practice. European Journal of Probation, 5(2): 47 - 65.

Bateman T (2017) The state of youth justice 2017. Report, National Association for Youth Justice, London.

Berg, M., Coman, E., \& Schensul, J. J. (2009). Youth action research for prevention: A multilevel intervention designed to increase efficacy and empowerment among urban youth.

American Journal of Community Psychology, 43(3), 345-359.

Byrne B and Lundy L (2019) Children's rights-based childhood policy: a six-P framework. The International Journal of Human Rights. 23 (3) 357-373.

Case S and Haines K (2009) Understanding Youth Offending: Risk Factor Research, Policy and Practice. Cullompton: Willan.

Case S and Haines K (2015) Children First, Offenders Second Positive Promotion: Reframing the Prevention Debate. Youth Justice, 15(3): 226 - 239.

Case S and Hampson K (2019) Youth Justice Pathways to Change: Drivers, Challenges and Opportunities. Youth Justice, 19 (1): 25-41.

Dowse L Cumming TM Strnadova I Lee J-S and Trofimovs J (2014) Young People with Complex Needs in the Criminal Justice System. Research and Practice in Intellectual and Developmental Disabilities 1(2): 174 - 185.

Department of Children and Youth Affairs (2015) National Strategy on Children and Young People's Participation in Decision-making, 2015 - 2020. Dublin: Government Publications. Available at: www.dcya.ie (accessed, November $1^{\text {st }} 2019$ ).

Fals Borda, O (1987). The application of participatory action-research in Latin America. International Sociology, 2, 329-347.

Fear R Rosaen C Bawden R and Foster-Fishman P (2006) Coming to critical engagement: An autoethnographic exploration of engaged faculty lives. Lanham, MD: University Press of America. 
Iwasaki, Y., Springett, J., Dashora, P., McLaughlin, A.-M., McHugh, T.-L., \& Youth 4 Yeg Team. (2014). Youth-guided youth engagement: Participatory action research (PAR) with high-risk, marginalized youth. Child \& Youth Services, 35(4), 316-342.

Kidd, S. A., \& Kral, M. J. (2005). Practicing participatory action research. Journal of Counseling Psychology, 52(2), 187-195.

Kim, J. (2016) Youth Involvement in Participatory Action Research (PAR): Challenges and Barriers. Critical Social Work 17 (1), 38-53.

Fischer J Jenkins N Bloor M Neale J and Berney L (2007) Drug user involvement in treatment decisions. York: Joseph Rowntree Foundation.

Fitzpatrick C and Williams P (2017) The neglected needs of care leavers in the criminal justice system: Practitioners' perspectives and the persistence of problem (corporate) parenting. Criminology and Criminal Justice 17(2): 175 - 191.

Fitzpatrick E McGuire J and Dickson J (2015) Personal goals of adolescents in a youth offending service in the United Kingdom. Youth Justice 15(2): 166 - 181.

Franks, M. (2011) Pockets of Participation: Revisiting Child-Centred Participation. Children and Society, 25 (1): 15-25.

Gadd D and Farrall S (2004) Criminal Careers, Desistance and Subjectivity: Interpreting Men's Narratives of Change. Theoretical Criminology, 8(2): 123 - 156.

Gadda A Harris J Tisdall K Millership E and Kilkelly U (2019) Human rights' monitoring and implementation: how to make rights 'real' in children's lives. International Journal of Human Rights 23 (3): 317-322.

Giordano PC Cernkovich SA and Rudolph JL (2002) Gender, crime, and desistance: Toward a theory of cognitive transformation. American Journal of Sociology 107(4): 990 - 1064.

Goldson B (2010) The sleep of (criminological) reason: Knowledge-policy rupture and New Labour's youth justice legacy. Criminology and Criminal Justice 10(1): 155 - 178.

Gray P (2009) The political economy of risk and the new governance of youth crime. Punishment and Society 11(4): 443 - 458.

Gyateng T Moretti A May T and Turnbull P (2013) Young People and the Secure Estate: Needs and Interventions. London: Youth Justice Board.

Haines K Case S Davies K and Charles A (2013) The Swansea Bureau: A Model of Diversion from the Youth Justice System. International Journal of Law, Crime and Justice, 41(2): 167 187.

Haines K and Case S (2015a) Positive Youth Justice: Children First, Offenders Second. Bristol: Policy Press.

Haines, K. and Case S (2018) The Future of Youth Justice. Youth Justice 18(2): 131 - 148.

Hampson K (2018) Desistance approaches in youth justice - The next passing fad or a seachange for the positive? Youth Justice 18(1): 18 - 33.

Hawkins JD Herrenkohl TI Farrington DP Brewer D Catalano RF Harachi TW and Cothern L (2000) Predictors of Youth Violence. Juvenile Justice Bulletin. Available at: http://files.eric.ed.gov/fulltext/ED440196.pdf (accessed 28th March 2019).

Her Majesty's Inspectorate of Probation [HMIP] (2017) Joint inspection of youth offending teams. Available at: www.justiceinspectorates.gov.uk/hmic/our-work/joint-inspections/jointinspection-of-youthoffending-teams/ (accessed 20th March 2018).

Johns D Williams K and Haines K (2016) Ecological youth justice: Understanding the social ecology of young people's prolific offending. Youth Justice 17(1): 3 - 21.

Jump, D. and Smithson, H. (2020) Dropping your Guard: The Use of Boxing as a Means of Forming Desistance Narratives Amongst Young People in the Criminal Justice System. The International Journal of Sport and Society, 11 (2). pp. 56-69. 
Kilkelly, U (2019) The UN convention on the rights of the child: incremental and transformative approaches to legal implementation. International Journal of Human Rights. 23(3), 323-337.

Lightowler C and Cook O (2015) Youth in Justice: Young People Explore What Their Role in Improving Youth Justice Might Be. Centre for Youth and Criminal Justice, University of Strathclyde, Glasgow: 1-33.

London JK Zimmerman K and Erbstein N (2003) Youth-led research and evaluation: Tools for youth, organizational and community development. New Directions for Evaluation 98: 33 - 45. Lundy L (2007) 'Voice' Is Not Enough: Conceptualising Article 12 of the United Nations Convention on the Rights of the Child. British Educational Research Journal, 33, (6) 927-942. McMahon G and Jump D (2018) Starting to Stop: Young Offenders' Desistance from Crime. Youth Justice 18(1): 3 - 17.

McNeill F Anderson K Colvin S Overy K Sparks R and Tett L (2011) Kunstprojecten en 'what works'; een stimulans voor desistance?' ['Inspiring Desistance? Arts projects and 'what works?']. Justitiele verkenningen 37(5): 80 - 101.

McNeill F Farrall S Lightowler C and Maruna S (2013) Desistance as a framework for supervision.

http://blogs.iriss.org.uk/discoveringdesistance/files/2013/09/McNeill-et-

al Desistance Frame.pdf (accessed 18 March 2018).

Muncie J (2009) Youth and crime (3rd Edition). London: Sage Publications.

Nacro Cymru (2009). Youth justice and participation in Wales. Cardiff: Nacro Cymru.

New Economics Foundation [NEF] (2009). A guide to co-producing children's services. London: New Economics Foundation.

National Youth Agency [NYA] (2010). Voice and influence in the youth justice system, Leicester: National Youth Agency.

Nugent B (2014) Reaching the 'hardest to reach'. Youth Justice 15(3): 271 - 285.

Nunn, C. (2010) 'Spaces to speak: Challenging representations of Sudanese Australians' Journal of Intercultural Studies 31(2):183-198.

Ozer EJ (2016) Youth-led Participatory Action Research. In Jason L and Glenwick D (eds) Handbook of methodological approaches to community-based research: Qualitative, quantitative and mixed methods, New York: Oxford University Press, pp. 263 - 272.

Phoenix J (2016) Against youth justice and youth governance, for youth penality. British Journal of Criminology 56(1): 123 - 140.

Phoenix J and Kelly L (2013) 'You have to do it for yourself': Responsibilization in youth justice and young people's situated knowledge of youth justice practice. British Journal of Criminology 53(3): 419 - 437.

Public Health England (2015) Service user involvement. A guide for drug and alcohol commissioners, providers and service users. London: Public Health England.

Sanders RA (2013) Adolescent psychosocial, social, and cognitive development. Pediatrics in Review/American Academy of Pediatrics 34(8): 354 - 358.

Scottish Government (2015) Preventing Offending: Getting it right for children and young people. Edinburgh: Scottish Government.

Scottish Government (2018) Delivering for Today, Investing for Tomorrow. https://www.gov.scot/binaries/content/documents/govscot/publications/publication/2018/09/d elivering-today-investing-tomorrow-governments-programme-scotland-201819/documents/00539972-. (Accessed $1^{\text {st }}$ November, 2019).

Scraton P and Haydon D (2002) Challenging the criminalization of children and children: securing a rights-based agenda. In Muncie J, Hughes G and McLaughlin E (eds) Youth Justice: Critical Readings, London: Sage, pp. 311 -328. 
Smith R (2014) Towards a 'welfare + rights' model in youth justice. Critical and Radical Social Work 2(3): $287-303$.

Smith R and Gray P (2018) The changing shape of youth justice: Models of practice. Criminology and Criminal Justice 19(5): 554-571.

Thew, H., Middlemiss, L. and Paavola, J. (2020) Youth is not a political position": Exploring justice claims-making in the UN Climate Change Negotiations. Global Environmental

Change 61, 102036.

United Nations Committee (UNCRC) General comment No. 24 (2019) on children's rights in the child justice system. UN Committee on the rights of the child. Geneva: Office of the High Commissioner for Human Rights.

United Nations Committee on the Rights of the Child [UNCRC] (2007) Forty-fourth session: General Comment No. 10 (2007) Children's Rights in Juvenile Justice. Geneva: Office of the High Commissioner for Human Rights.

United Nations Committee on the Rights of the Child [UNCRC] (2008) Concluding observations of the UN committee on the rights of the child. Geneva: UNICEF.

Vaughan, C. (2014) Participatory research with youth: Idealising safe social spaces or building transformative links in difficult environments? Journal of Health Psychology 19(1) 184- 92.

Winn, M.T. (2010) 'Our side of the story': moving incarcerated youth voices from margins to center. Race Ethnicity and Education, 13:3, 313-325.

Youth Justice Board [YJB] (2016) Participation strategy: Giving young people a voice in youth justice. London: YJB.

\footnotetext{
${ }^{i}$ By way of context, the Knowledge Transfer Partnership (KTP) scheme is a UK-wide government funded programme that enables a business to bring in new skills and the latest academic thinking to deliver a specific, strategic innovation project through a knowledge-based partnership (https://www.gov.uk/guidance/knowledgetransfer-partnerships-what-they-are-and-how-to-apply).
} 